\title{
Pengembangan Multimedia Interaktif dengan Aplikasi Autorun Pro Enterprise II pada Mata Kuliah Komputer Multimedia di Program Studi Teknologi Pendidikan
}

\author{
Nofri Hendri, Novrianti \\ Universitas Negeri Padang, Padang \\ Email: nofrihendritp@gmail.com
}

\begin{abstract}
This type of research is research development (Research and Development / R \& D). This research uses Borg and Gall development model with a modified step that is (1) Doing Planning, (2) Developing the initial product, (3) Conducting product validation, (4) Conducting a limited trial and (5) Result of the final product. The product validity test is done by three validators, two media validators, and one material validator. The product test was conducted to 21 students of the FTP UNP Department of KTP who took the Multimedia Computer Courses semester JulyDecember 2017. The instruments used were a questionnaire, assessment format, and documentation. Data were analyzed descriptively quantitative to know the quality of interactive multimedia developed. The results of the analysis show that interactive multimedia for multimedia learning, in the material aspect is in the "Good" category, for the media aspect is in the "Very Good" category. Furthermore, the results of product practicality test that has been done is in the category of "Very Good". These results show that interactive multimedia is practically used as a source of learning and alternative media in multimedia learning.
\end{abstract}

Keywords: Research and Development, Multimedia, Interactive, Autorun Pro Enterprise

\section{PENDAHULUAN}

Perkembangan teknologi seperti teknologi multimedia itu sendiri sangat bermanfaat sebagai media pembelajaran agar peserta didik mendapatkan informasi-informasi penting baginya, sekaligus langsung mengalami proses pembelajaran (Rahmat, 2015). Pembelajaran yang dialami oleh peserta didik tersebut dapat mengembangkan pemahaman berpikir secara realita, konkret dan mengajarkan peserta didik berpikir kritis. Salah satu media yang dapat merangsang mahasiswa agar terjadi proses belajar yang baik adalah dengan penggunaan multimedia interaktif (Adam \& Syastra, 2015).

Berdasarkan studi pendahuluan yang dilakukan di jurusan KTP FIP UNP pada perkuliahan komputer multimedia didapat sejumlah informasi yakni belum terdapatnya sebuah media pembelajaran menggunakan program ini. Oleh karena itu, perlu adanya 
pengembangan tentang program Autorun Pro Enterprise II.

Berdasarkan uraian di atas, maka dapat dirumuskan permasalahan pada aspek-aspek berikut:

1. Bagaimana pengembangan multimedia interaktif dengan aplikasi autorun pro enterprise II pada mata kuliah komputer multimedia di program studi Teknologi Pendidikan yang valid?

2. Bagaimana pengembangan multimedia interaktif dengan aplikasi autorun pro enterprise II pada mata kuliah komputer multimedia di program studi Teknologi Pendidikan yang praktis?

Adapun tujuan yang ingin dicapai dalam penelitian ini adalah:

1. Menghasilkan media pembelajaran dengan program Autorun Pro Enterprise II yang valid sesuai dengan kriteria kelayakan media pembelajaran.

2. Mengetahui kepraktisan media pembelajaran dengan program Autorun Pro Enterprise II pada pembelajarankomputer multimedia.

Pengembangan media pembelajaran interaktif ini dilakukan sebagai upaya untuk memecahkan beragam permasalahan yang terdapat dalam pengembangan media pembelajaran (Arda, Saehana, \& Darsikin, 2015). Terutama peneliti sebagai pengajar di Jurusan KTP FIP UNP memiliki tugas untuk mengembangkan sebuah media pembelajaran karena hal tersebut adalah bentuk perwujudan terhadap visi dan misi jurusan KTP FIP UNP. Asumsi lainnya adalah berdasarkan pengembangan kawasan Teknologi Pendidikan sebagai perekayasa pembelajaran dan pendidikan Teknologi Informasi \& Komunikasi serta pendidikan pada umumnya sehingga melahirkan inovasi yang bermakna bagi pembangunan.

\section{METODE}

Jenis penelitian ini adalah penelitian pengembangan yang dikenal dengan istilah Research and Development (R\&D). Menurut Sugiyono dalam Nopriyanti \& Sudira (2015) metode penelitian dan pengembangan adalah metode penelitian yang digunakan untuk menghasilkan produk tertentu, dan menguji keefektivan produk tertentu.

Penelitian Pengembangan multimedia interaktif dengan aplikasi Autorun Pro Enterprise II ini menggunakan model yang dikemukan oleh Borg dan Gall. Model pengembangan merupakan dasar untuk mengembangkan produk yang dihasilkan. Model yang dikemukan oleh Borg dan Gall dalam Emzir (2012). Borg dan Gall mengemukakan bahwa dalam penelitian dan pengembangan terdapat beberapa langkah yang bersifat siklus, yaitu:

1. Penelitian dan pengumpulan informasi

2. Perencanaan

3. Pengembangan produk awal produk

4. Uji lapangan awal

5. Revisi produk

6. Uji lapangan utama

7. Revisi produk operasional

8. Uji lapangan operasional

9. Revisi produk akhir

10. Diseminasi dan implementasi

Borg dan Gall dalam Emzir (2012) juga menyarankan untuk membatasi penelitian dalam skala kecil, termasuk dimungkinkan membatasi langkah penelitian. Oleh karena itu dalam penelitian ini, peneliti menyederhanakan langkah tersebut sesuai dengan kebutuhan peneliti menjadi lima langkah penelitian, yaitu:

1. Melakukan perencanaan (observasi lapangan dan studi pendahuluan)

2. Mengembangkan produk awal

3. Melakukan validitas produk (validitas dan revisi)

4. Melakukan uji coba terbatas.

5. Hasil produk akhir

Dalam penelitian ini menggunakan beberapa instrumen untuk mendapatkan informasi untuk mendukung pengembangan multimedia. Berikut adalah instrumeninstrumen yang digunakan pada penelitian ini.

\section{Angket Validitas}

Lembar angket ini diberikan kepada validator untuk mengetahui tentang tingkatan validitas materi dan media pembelajaran. Adapun kisi kisi untuk ahli materi dan ahli media dapat dilihat pada Tabel 1 . 
Tabel 1.

Kisi-kisi Penilaian Ahli Materi dan Ahli Media

\begin{tabular}{|c|c|c|c|}
\hline Aspek & $\begin{array}{l}\text { Varabel Kriteria } \\
\text { multimedia }\end{array}$ & Indikator & Butir instrument \\
\hline \multirow[t]{13}{*}{ 1. Materi } & \multirow[t]{3}{*}{$\begin{array}{l}\text { 1.1. Kebenaran } \\
\text { konsep }\end{array}$} & $\begin{array}{l}\text { 1. Kesesuaian learning } \\
\text { outcomes, soft skill, }\end{array}$ & $\begin{array}{l}\text { 1. Kesesuaian materi dengan } \\
\text { kurikulum }\end{array}$ \\
\hline & & dan Indikator dengan & 2. Kesesuaian materi dengan LO \\
\hline & & materi & $\begin{array}{l}\text { 3. Kesesuaian materi dengan } \\
\text { indikator }\end{array}$ \\
\hline & \multirow[t]{3}{*}{ 1.2.Penyajian materi } & $\begin{array}{l}\text { 1. Ketepatan penyajian } \\
\text { materi Komputer }\end{array}$ & $\begin{array}{l}\text { 4. Ketepatan sistematika penyejian } \\
\text { materi }\end{array}$ \\
\hline & & Multimedia & 5. Kecakupan isi materi \\
\hline & & $\begin{array}{l}\text { 2. Penyajian materi } \\
\text { berurutan }\end{array}$ & $\begin{array}{l}\text { 6. Kejelasan materi yang digunakan } \\
\text { 7. Keterbacaan teks }\end{array}$ \\
\hline & \multirow[t]{3}{*}{ 1.3.Penulisan } & 1. Menggunakan tata & 8. Kesesuaian penulisan dengan EYD \\
\hline & & bahasa yang baku & 9. Ketepatan penulisan istilah-istilah \\
\hline & & $\begin{array}{l}\text { dan dapat } \\
\text { dimengerti }\end{array}$ & 10. Ketepatan penggunaan tanda baca \\
\hline & \multirow[t]{4}{*}{ 1.4.Evaluasi } & $\begin{array}{l}\text { 1. Kesesuaian evaluasi } \\
\text { dengan materi }\end{array}$ & $\begin{array}{l}\text { 11. Ketepatan sistematika penyajian } \\
\text { soal }\end{array}$ \\
\hline & & & 12. Kesesuaian latihan dengan materi \\
\hline & & & 13. Kesesuaian latihan yang \\
\hline & & & $\begin{array}{l}\text { disediakan dengan pemahaman } \\
\text { anak dengan materi }\end{array}$ \\
\hline \multirow[t]{12}{*}{ 2. Media } & \multirow{6}{*}{$\begin{array}{l}\text { 2.1. Kesesuaian } \\
\text { Media }\end{array}$} & 1. Tampilan layout & 14. Kesesuaian tampilan layout \\
\hline & & 2. Kualitas tampilan & 15. Tata letak tampilan media \\
\hline & & $\begin{array}{l}\text { 3. Pemilihan komposisi } \\
\text { warna }\end{array}$ & $\begin{array}{l}\text { 16. Kesesuaian media gambar/foto } \\
\text { yang disajikan }\end{array}$ \\
\hline & & $\begin{array}{l}\text { 4. Pemilihan jenis dan } \\
\text { ukuran font }\end{array}$ & $\begin{array}{l}\text { 17. Kesesuaian } \\
\text { gambar/foto }\end{array}$ \\
\hline & & & $\begin{array}{l}\text { 18. Kesesuaian pemilihan komposisi } \\
\text { warna }\end{array}$ \\
\hline & & & 19. Materi yang disajikan berurutan \\
\hline & \multirow[t]{3}{*}{$\begin{array}{r}\text { 2.2.Desain } \\
\text { Layout }\end{array}$} & $\begin{array}{l}\text { 1. Sajian animasi } \\
\text { 2.Daya dukung musik }\end{array}$ & $\begin{array}{l}\text { 20. Kesesuaian desain background } \\
\text { yang digunakan }\end{array}$ \\
\hline & & 3. Navigasi & $\begin{array}{l}\text { 21. Kesesuaian animasi yang } \\
\text { ditampilkan }\end{array}$ \\
\hline & & & $\begin{array}{l}\text { 22. Ketepatan gambar yang disajikan } \\
\text { 23. Penempatan tombol navigasi } \\
\text { sesuai dengan kebutuhan } \\
\text { 24. Kesesuaian music pendukung }\end{array}$ \\
\hline & \multirow{3}{*}{$\begin{array}{l}2.3 \text { Kemudahan } \\
\text { penggunaan }\end{array}$} & 1. Kemudahan & 25. Kemudahan penggunaan media \\
\hline & & & $\begin{array}{l}\text { 26. Media yang digunakan memuat } \\
\text { langkah-langkah penggunaan }\end{array}$ \\
\hline & & & $\begin{array}{l}\text { 27. Penyajian media bersifat interaktif } \\
\text { dan memberikan umpan balik } \\
\text { kepada pemakai }\end{array}$ \\
\hline
\end{tabular}

\section{Angket Praktikalitas}

Untuk mengumpulkan data dalam rangka melihat praktikalitas produk ini adalah angket. Angket ini dirancang sesuai dengan kebutuhan dan disebarkan kepada subjek uji coba yakni mahasiswa program studi Teknologi Pendidikan FIP UNP. Angket yang diberikan meliputi aspek tampilan, kejelasan penyajian materi, dan 
kemanfaatan. Kisi-kisi instrument untuk mahasiswa dapat dilihat pada Tabel 2.

Tabel 2.

Kisi-kisi Angket Praktikalitas

\begin{tabular}{|c|c|c|c|}
\hline Aspek & $\begin{array}{c}\text { Variabel/Kriteria } \\
\text { Multimedia Interaktif }\end{array}$ & Indikator & Butir Instrument \\
\hline \multirow[t]{7}{*}{ Kepraktisan } & 3.1. Tampilan & $\begin{array}{l}\text { 1. Bahasa } \\
\text { 2. Navigasi } \\
\text { 3. Daya tarik tampilan }\end{array}$ & $\begin{array}{l}\text { 1. Bahasa yang digunakan mudah } \\
\text { dipahami } \\
\text { 2. Tombol navigasi mudah digunakan } \\
\text { 3. Tampilan multimedia menarik }\end{array}$ \\
\hline & $\begin{array}{l}\text { 3.2.Penyajian } \\
\text { Materi }\end{array}$ & $\begin{array}{l}\text { 1. Kejelasan dan } \\
\text { kemudahan }\end{array}$ & $\begin{array}{l}\text { 4. Materi yang disajikan mudah untuk } \\
\text { dipahami }\end{array}$ \\
\hline & & $\begin{array}{l}\text { 2. Urutan penyajian } \\
\text { materi } \\
\text { 3. Penggunaan animasi }\end{array}$ & $\begin{array}{l}\text { 5. Sistematika penyajian materi baik } \\
\text { 6. Gambar yang digunakan mudah } \\
\text { dipahami }\end{array}$ \\
\hline & & 4. Evaluasi & $\begin{array}{l}\text { 7. Tes yang diberikan sesuai denfan } \\
\text { materi }\end{array}$ \\
\hline & 3.3.Kemanfaatan & $\begin{array}{l}\text { 1. Kemudahan dalam } \\
\text { belajar }\end{array}$ & 8. Multimedia mempermudah belajar \\
\hline & & $\begin{array}{l}\text { 2. Motivasi belajar } \\
\text { 3. Ketertarikan }\end{array}$ & $\begin{array}{l}\text { 9. Multimedia interaktif dapat } \\
\text { meningkatkan motivasi belajar }\end{array}$ \\
\hline & & menggunakan media & $\begin{array}{l}\text { 10. Penggunaan media pembelajaran } \\
\text { interaktif menyenangkan }\end{array}$ \\
\hline
\end{tabular}

Teknik analisis yang digunakan adalah analisis deskriptif yang mendeskripsikan validitas dan kepraktisan media yang digunakan.

\section{Analisis Uji Validitas}

Analisis uji validitas dilakukan dengan beberapa langkah:

1. Memberikan skor jawaban dengan kriteria sebagai berikut:

Media interaktif yang

dikembangkan sebagai media pembelajaran yang divalidiasi diberi nilai 1-4 dengan kriteria sebagai berikut :

$$
\begin{aligned}
& 1=\text { Sangat tidak baik } \\
& 2=\text { Tidak baik } \\
& 3=\text { Baik } \\
& 4=\text { Sangat baik } \\
& \text { (Sudjana 1989: 105) }
\end{aligned}
$$

2. Menentukan skor yang diperoleh dengan menjumlahkan skor dari masing-masing validator

3. Pemberian nilai validitas dengan cara :

Nilai validitas $=$ Skor yang diperoleh $\mathrm{x}$ 100

$$
\text { Jumlah skor tertinggi }
$$

Memberikan penilaian validitas dengan kriteria:

$$
\begin{array}{lc}
\text { Valid tanpa revisi } & =100 \\
\text { Valid dengan revisi ringan } & =81-99 \\
\text { Valid dengan revisi sedang } & =61-80
\end{array}
$$

Tidak dapat digunakan $\quad=\leq 60$

Data tersebut akan dijadikan sebagai salah satu tolak ukur penilaian awal untuk menilai kualitas dari multimedia dan akan menjadi tolak ukur untuk melakukan revisi awal dari multimedia hingga dinyatakan layak digunakan subjek coba.

\section{Analisis Uji Kepraktisan Media yang Dikembangkan}

Angket uji kepraktisan dideskripsikan dengan teknik analisis frekuensi data dengan rumus:

Nilai kepraktisan

$$
=\frac{\text { skor rata }- \text { rata }}{\text { skor maksimal }} \times 100
$$

Analisis kepraktisan media interaktif sebagai media pembelajaran menggunakan analisis deskriptif, dengan kriteria sebagai berikut:

$$
\begin{array}{ll}
0-59 & =\text { Sangat tidak praktis } \\
60-69 & =\text { Tidak praktis } \\
70-79 & =\text { Praktis } \\
80-100 & =\text { Sangat praktis }
\end{array}
$$

\section{HASIL PENGEMBANGAN DAN PEMBAHASAN}

\section{Hasil Pengembangan}

Hasil Perencanaan 
Setelah melakukan observasi lapangan dan studi pendahuluan maka multimedia interakif yang dikembangkan adalah dengan menggunakan aplikasi Autorun Enterprise II pada mata kuliah komputer multimedia semester Juli-Desember 2017.Selanjutnya dilakukan pengumpulan materi pokok dengan menggunakan sumber atau buku mata pelajaran sudah ada dan tambahan dari internet. Selain itu, materi yang akan di muat pada media juga dibuat berdasarkan silabus dan RPP yang sudah ada.

\section{Pengembangan Produk Awal}

Setelah melakukan analisis pada perencanaan dan mengumpukan materi, peneliti mulai mengembangkan produk. Dalam penyiapan bahan-bahan pelaksanaan pengembangan multimedia interaktif, peneliti mengumpulkan bahan yang dibutuhkan. Bahan yang peneliti kumpulkan berupa materi pembelajaran yang akan dikembangkan, gambar pendukung, suara, video, dan animasi. Selain itu, bahan yang digunakan juga diproduksi terlebih dahulu, seperti background, animasi, suara, dan video. Bahan untuk background dibuat menggunakan aplikasi photoshop. Pada pembuatannya, background dipilih berdasarkan materi yang akan dipelajari. Bahan animasi dibuat menggunakan Macromedia Flash. Animasi yang terdapat dalam media adalah dibuat hampir untuk keseluruhan halaman materi, misalnya pada gambar dan teks. Peran animasi pada media adalah sebagai penekanan mengenai materi komputer multimedia.

Sedangkan untuk video menggunakan aplikasi Ulead Video Studio.Video yang digunakan dalam media ini yaitu tentang langkah-langkah pembuatan multimedia yang dibuat sendiri dan diambil dari youtube. Video yang awalnya menjelaskan semua tentang langkah-langkah pembuatan multimedia kemudian menjadi beberapa video yang nantinya digunakan pada masing-masing materi. Hasilnya adalah video yang sesuai dengan materi yang akan dipelajari. Dalam media hanya terdapat beberapa materi yang menggunakan video, karena tuntutan dari masing-masing materi yang akan dipelajari berbeda-beda.
Pemilihan audio/suara dalam media menggunakan instrument musik yang telah ada. Instrument yang digunakan adalah soundtrack pada salah satu game RPG (Role Playing Game). Pemilihan musik ini dipilih karena media yang diproduksi akan digunakan oleh mahasiswa. Instrument tersebut diedit dengan menggunakan aplikasi Cool Edit Pro. Hasil dari instrument yang diedit adalah musik instrument dengan nada yang lebih tinggi/rendah sesuai dengan kebutuhan. Selain itu, suara narrator juga diedit menggunakan aplikasi ini. Kegunaannya adalah agar suara narator lebih jelas.

Materi yang akan disajikan dalam media berdasarkan silabus dan RPP yang diberikan oleh dosen yang bersangkutan. Pemilihan materi ini berdasarkan saran yang diberikan oleh dosen pada saat observasi, yaitu pada materi ini media yang digunakan hanya media cetak. Penjelasan materi akan lebih baik jika menggunakan multimedia interaktif.

Semua bahan tersebut nantinya akan digabungkan kedalam sebuah multimedia interaktif menggunakan aplikasi Autorun Pro Enterprise II. Sesuai dengan spesifikasi produk yang digunakan, cukup dengan klikdrag \&drop maka akan jadi sebuah halaman yang diinginkan.

Setelah semua disiapkan, selanjutnya adalah menggabungkan bahan sesuai dengan flowchart dan storyboard. Flowchart dibuat sedemikian rupa sesuai dengan materi yang ada dan kebutuhan mahasiswa berdasarkan observasi, kemudian dilanjutkan dengan storyboard.

Setelah storyboard dibuat langkah selanjutnya adalah membuat media dengan menggunakan aplikasi Autorun Pro Enterprise II. Dalam pembuatan media, perancang membuatnya sendiri. Semua bahan yang telah disiapkan tadi digabungkan untuk menghasilkan media yang akan divalidasi. Pengembangan produk awal ini disesuaikan dengan spesifikasi produk yang diharapkan, sehingga menghasilkan multimedia interaktif yang dapat menjadi sarana pendukung belajar bagi mahasiswa.

\section{Validasi Produk}

\section{Validasi Produk oleh Ahli}


Selanjutnya adalah melakukan validasi terhadap produk yang dikembangkan. Validasi ini dilakukan untuk mengetahui validitas produk multimedia interaktif yang telah dibuat. Validasi pada pengembangan produk ini melibatkan 2 orang ahli media dan ahli materi adalah 1 orang dosen mata kuliah Komputer Multimedia.

\section{$\underline{\text { Revisi }}$}

Setelah mendapatkan masukan dari ahli media dan ahli materi, dilanjutkan merevisi produk yang telah dibuat sesuai dengan saran yang diberikan. Revisi dilakukan untuk memperbaiki produk sebelum dilakukan uji coba pratikalitas terhadap mahasiswa Jurusan KTP FIP UNP yang mengambil mata kuliah komputer multimedia semester Juli-Desember 2017 dengan kode seksi KTP175.Setelah dilakukan revisi, produk dikonsultasikan lagi kepada ahli untuk mengetahui apakah media sudah layak untuk diujicobakan kepada mahasiswa.

\section{Uji Coba}

Uji coba dilakukan untuk mengetahui pratikalitas penggunaan media dengan melibatkan mahasiswa Jurusan KTP FIP UNP yang mengambil mata kuliah komputer multimedia semester Juli-Desember 2017 dengan kode seksi KTP175. Pengumpulan data dilakukan dengan menampilkan program di komputer dan siswa menggunakan produk kemudian menyebarkan angket penilaian yang nantinya diisi oleh siswa. Angket penilaian untuk siswa meliputi aspek tampilan, kemudahan penggunaan, aspek penyajian materi dan aspek kemanfaatan .

\section{Hasil Produk Akhir}

Setelah berbagai prosedur yang dilakukan, maka dihasilkan sebuah multimedia interaktif menggunakan aplikasi Autorun Pro Enterprise II. Validasi dan uji coba yang sudah dilakukan akan diperoleh hasil penelitian dan pengembangan berupa produk yang dapat digunakan sebagai media pembelajaran.

\section{Deskripsi Pengembangan Produk dan Hasil Uji Coba}

\section{Deskripsi Data Validasi}

\section{$\underline{\text { Ahli Materi }}$}

Data validasi diperoleh dari ahli materi yang merupakan dosen mata kuliah komputer multimedia semester Juli-Desember 2017, dengan cara memberikan lembar penilaian. Ahli materi mencoba produk dengan didampingi oleh perancang media, sehingga ahli materi dapat menanyakan langsung hal-hal yang berkaitan dengan produk yang dikembangakan dan dapat langsung memberikan masukan berupa kritik dan saran kepada pengembang yang natinya akan digunakan sebagai pedoman untuk melakukan revisi terhadap produk yang dikembangkan. Hasil perolehan penilaian materi yang mencangkup aspek kebenaran konsep, penyajian materi, penulisan, dan evaluasi dari ahli materi.

Berdasarkan hasil penilaian dari ahli materi menunjukkan bahwa media pembelajaran multimedia interaktif termasuk kepada kategori "Baik" dengan skor rata rata 3,43. Data penilaian ahli materi ditinjau dari (1) Kebenaran konsep yang dijabarkan menjadi 3 butir pertanyaan memperoleh rerata sebesar 83,33 dengan kriteria "valid dengan revisi ringan" (2) Penyajian materi yang dijabarkan menjadi 5 butir pertanyaan memperoleh rerata sebesar 85 dengan kriteria "valid dengan revisi ringan", (3) Penulisan yang dijabarkan menjadi 3 butir pertanyaan memperoleh rerata sebesar 83,33 dengan kriteria "valid dengan revisi ringan (4) Evaluasi yang dijabarkan menjadi 3 butir pertanyaan memperoleh rerata sebesar 91,67 dengan kriteria "valid dengan revisi ringan".

Secara keseluruhan, tingkat validasi dari ahli media memproleh rata-rata sebesar 85,71dengan kriteria "valid dengan revisi ringan". Angka yang diperoleh menunjukkan bahwa media pembelajaran multimedia interaktif ini dapat digunakan setelah revisi ringan.

\section{$\underline{\text { Ahli Media }}$}

Ahli media terdiri dari 2 orang dosen jurusan KTP FIP UNP. Ahli media mengkaji aspek-aspek media yang ada pada variabel yang telah dirancang dengan cara memberikan angket. Ahli media mencobakan produk yang didampingi oleh perancang media sehingga dapat langsung diberikan masukan berupa kriktik dan saran kepada pengembang yang 
nantinya akan digunakan sebagai pedoman untuk melakukan revisi terhadap produk yang dikembangakan.

Hasil perolehan penilaian media yang mencangkup aspek kesesuaian media, desain dan layout dan kemudahan penggunaan. Berdasarkan hasil penilaian dari ahli media menunjukkan bahwa media perlu direvisi pada item 3, karena termasuk dalam kategori "Tidak Baik". Item 3 yaitu kesesuaian media gambar/foto yang disajikan. Pada item 4 dan 10 termasuk dalam kategori "baik" dan masih perlu revisi, item 4 yaitu kesesuaian penempatan gambar/foto, dan item 10 yaitu ketepatan gambar yang disajikan.

Pembelajaran

menggunakan

multimedia interaktif dari aspek media secara keseluruhan termasuk kepada kategori “ Sangat Baik", dengan rata-rata skor 3,6.Data penilaian ahli media ditinjau dari (1) Kesesuaian media yang dijabarkan menjadi 7 butir pertanyaan memperoleh rerata sebesar 89.29 dengan kriteria "valid dengan revisi ringan" (2) Desain dan layout yang dijabarkan menjadi 5 butir pertanyaan memperoleh rerata sebesar 87,50 dengan kriteria "valid dengan revisi sedang", (3) Kemudahan penggunaan yang dijabarkan menjadi 3 butir pertanyaan memperoleh rerata sebesar 95.83 dengan kriteria "valid dengan revisi ringan".

Secara keseluruhan, tingkat validasi dari ahli media memproleh rerata sebesar 90,87 dengan kriteria "valid dengan revisi ringan". Angka yang diperoleh menunjukkan bahwa media pembelajaran ini dapat digunakan setelah revisi ringan.

\section{Deskripsi Data Pratikalitas}

Setelah produk divalidasi oleh validator, maka produk di uji cobakan. Uji coba dilakukan dengan melibatkan 21 responden yang merupakan mahasiswa yang mengambil mata kuliah komputer multimedia pada kode seksi KTP175. Jumlah mahasiswa sesi tersebut sebenarnya ada 26 orang, namun karena berbagai alasan pada saat itu hanya hadir 21 orang. Data dalam tahap ini data primer yaitu berupa data yang langsung diperoleh dari mahasiswa sebagai subjek coba. Hasil data uji coba media pembelajaran multimedia interakifdapat disimpulkan ratarata nilai praktikalitas adalah 3.60 dengan kategori "Sangat Baik". Mahasiswa menggangap media ini sangat praktis digunakan. Data penilaian hasil uji coba multimedia interaktif ditinjau dari (1) tampilan media yang dijabarkan menjadi 3 butir pertanyaan memperoleh rerata sebesar 82,94 dengan kriteria "sangat praktis" (2) penyajian materi yang dijabarkan menjadi 4 butir pertanyaan memperoleh rerata sebesar 88,10 dengan kriteria "sangat praktis dan (3) kemanfaatan yang dijabarkan menjadi 3 butir pertanyaan memperoleh rerata sebesar 90,08 dengan kriteria sangat praktis. Secara keseluruhan, tingkat pratikalitas dari hasil uji coba pada siswa memproleh rerata sebesar 88,10 dengan kriteria "sangat praktis". Berdasarkan data praktikalitas oleh mahasiswa jurusan KTP FIP UNP yang mengambil mata kuliah komputer multimedia pada semester Juli-Desember 2017 pada seksi KTP 175 dapat diketahui bahwa dari aspek yang dinilai secara umum respon mahasiswa terhadap media yang digunakan adalah positif dengan kriteria sangat praktis.

\section{Revisi Produk}

Berdasarkan hasil validasi multimedia interaktif pada mata kuliah komputer multimedia di atas, dapat disimpulkan bahwa secara keseluruhan aspek materi, media, dan kepraktisan produk yang dikembangkan termasuk dalam valid dengan revisi ringan.

Revisi yang dilakukan sesuai dengan komentar atau saran dari para ahli yang telah dibuat dalam lembar penilaian. Menurut saran ahli materi seperti berikut:

1. Perlu adanya penambahan materi karena masih sedikit.

2. Perlu penambahan beberapa ilustrasi yang sesuai.

Untuk lebih jelasnya akan digambarkan pada Tabel 3 . 
Tabel 3.

Uraian Revisi Materi

\begin{tabular}{|c|c|c|}
\hline Revisi & Sebelum Revisi & Sesudah Revisi \\
\hline 1 & 2 & 3 \\
\hline \multirow{5}{*}{$\begin{array}{c}\text { Tambahan } \\
\text { materi }\end{array}$} & h & 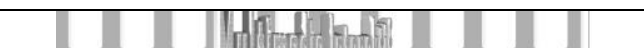 \\
\hline & MATA RULIAW KOMPUTEm MULTUMEDIA & \\
\hline & 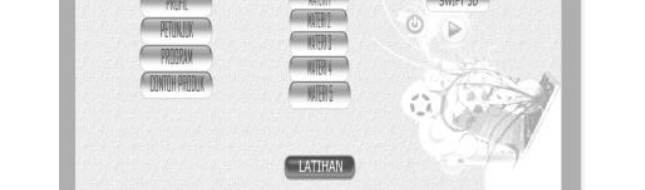 & 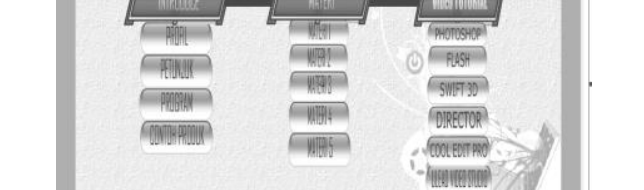 \\
\hline & 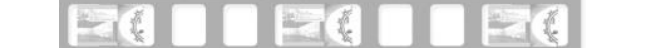 & $=$ \\
\hline & $\begin{array}{l}\text { Materi masih sedikit, bisa dilihat dari jumlah } \\
\text { page media hanya } 4 . \text { Tambahan materi } \\
\text { terdapat pada materi BAB } 1 .\end{array}$ & $\begin{array}{l}\text { Materi ditambahkan lebih banyak bisa } \\
\text { dilihat pada jumlah page media menjadi } 6 \text {. } \\
\text { Materi yang ditambahkan berupa penjelasan } \\
\text { lebih mengenai materi yang terdapat pada } \\
\text { BAB } 2 \text {. }\end{array}$ \\
\hline $\begin{array}{l}\text { Tambahan } \\
\text { ilustrasi } \\
\text { berupa }\end{array}$ & $\begin{array}{l}\text { TAHAPAR PRODUHSI } \\
\text { mULTIMEDIA InTERAKTIF }\end{array}$ & $\begin{array}{l}\text { TAHAPคA PRODUHSI } \\
\text { mULTIMEDIA IOTERAKTIF }\end{array}$ \\
\hline $\begin{array}{c}\text { gambar yang } \\
\text { mendukung } \\
\text { materi }\end{array}$ & $\begin{array}{l}\text { - Prapraduksi } \\
\text { - Praduksi } \\
\text { - Pascaproduksi }\end{array}$ & $\begin{array}{l}\text { - Praproduksi } \\
\text { - Praduksi } \\
\text { - Pascaproduksi }\end{array}$ \\
\hline & $\begin{array}{l}\text { Sebelum revisi gambar yang digunakan } \\
\text { masih kurang. Ini terlihat pada halaman } \\
\text { materi, banyaknya tempat yang masih } \\
\text { kosong dan tampak kurang bagus. }\end{array}$ & $\begin{array}{l}\text { Gambar yang berkaitan dengan materi } \\
\text { ditambahkan pada halaman media untuk } \\
\text { menekankan materi yang dirasa perlu } \\
\text { penjelasan }\end{array}$ \\
\hline
\end{tabular}

Selain saran ahli materi tersebut, revisi juga dilakukan sesuai dengan saran dari ahli media sebagai berikut:

1. Perbesar tampilan awal menu

2. Setiap materi tambahkan dengan gambar.

3. Kurangi paparan dalam bentuk tulisan.

4. Perbanyak gambar.

5. Pada judul-judul besar di buat lebih menarik.

6. Musik media 1 untuk semua halaman.

7. Menu musik pada halaman utama dihilangkan saja.
8. Perbaiki tata tulis pada materi.

9. Pada menu Glosarium, Daftar Pustaka, Panduan, Profil di tampilkan satu-satu.

10. Hilangkan tombol "next" dan "prev" pada halaman "gambar" di tiap materi.

11. Pada halaman "panduan" dijelaskan secara detail kegunaan dari masing-masing tombol.

12. Tambah narrative speaker untuk materi.

Untuk lebih jelasnya akan digambarkan pada tabel 4 . 
Tabel 4.

Uraian Revisi Media

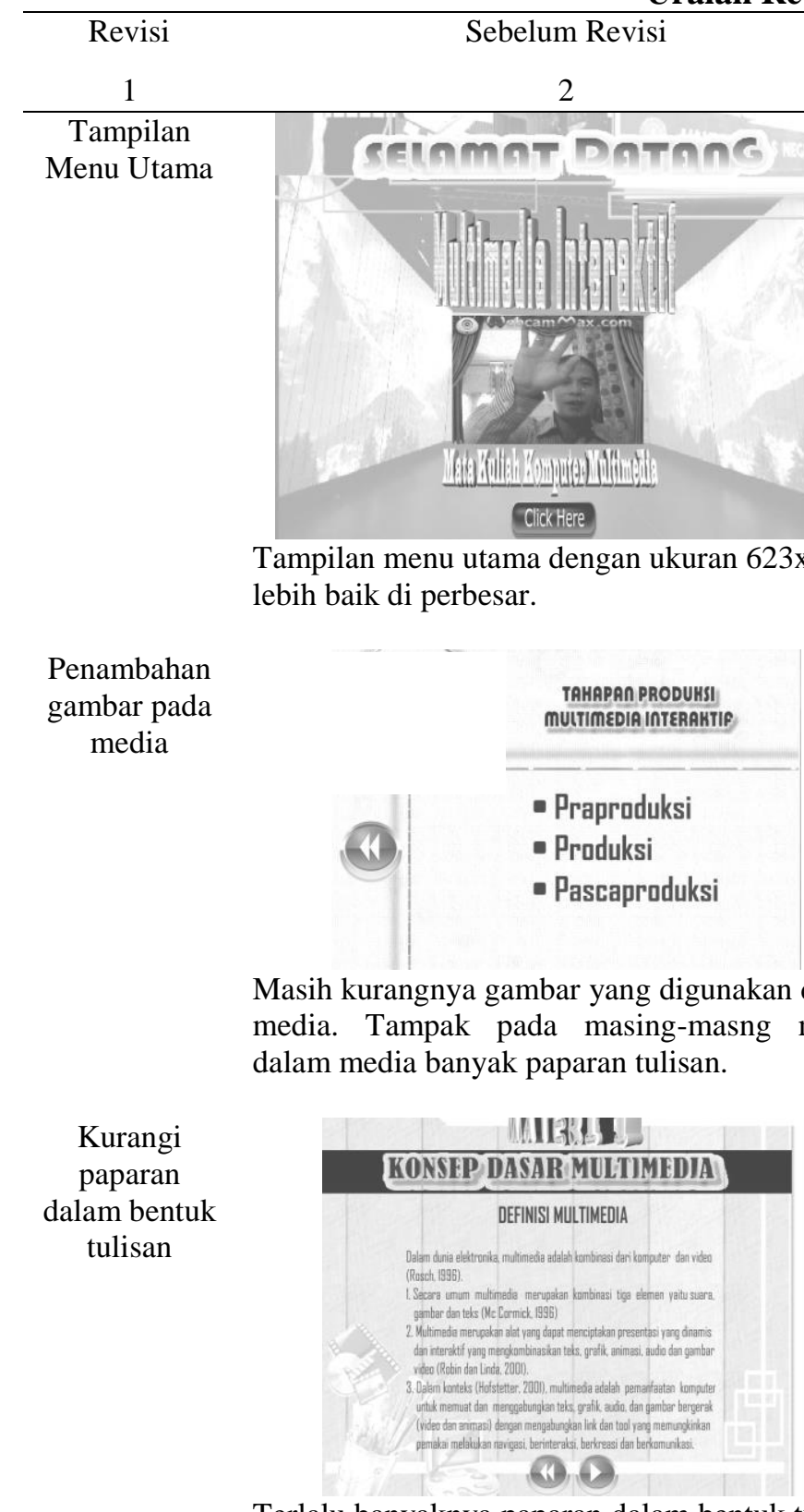

Terlalu banyaknya paparan dalam bentuk tulisan sehingga media terlihat membosankan.

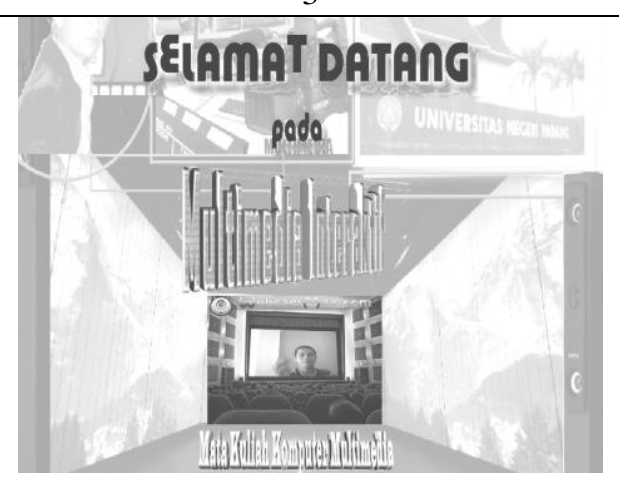

Sesudah revisi tampilan utama diperbesar dengan resolusi 800x600 pixel.

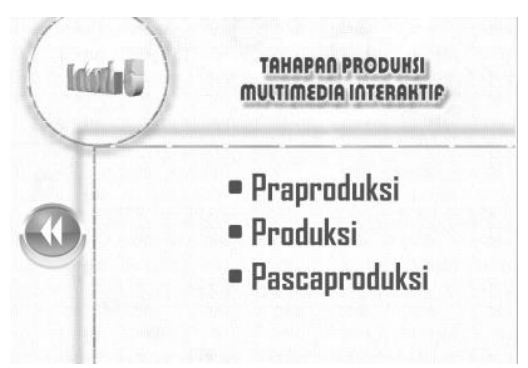

Gambar yang berkaitan dengan materi ditambahakan untuk memperjelas materi yang dituliskan.

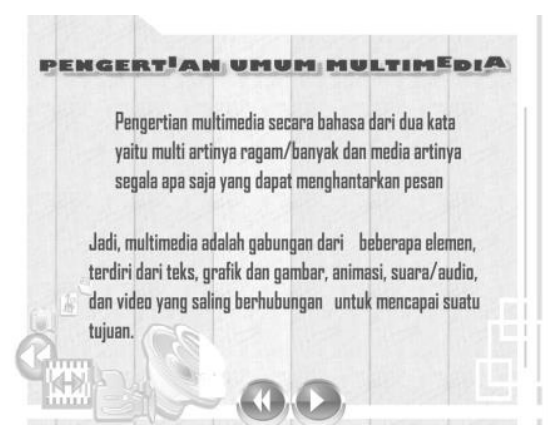

Paparan dalam bentuk tulisan dikurangi dengan menambahkan gambar yang berkaitan dengan materi.

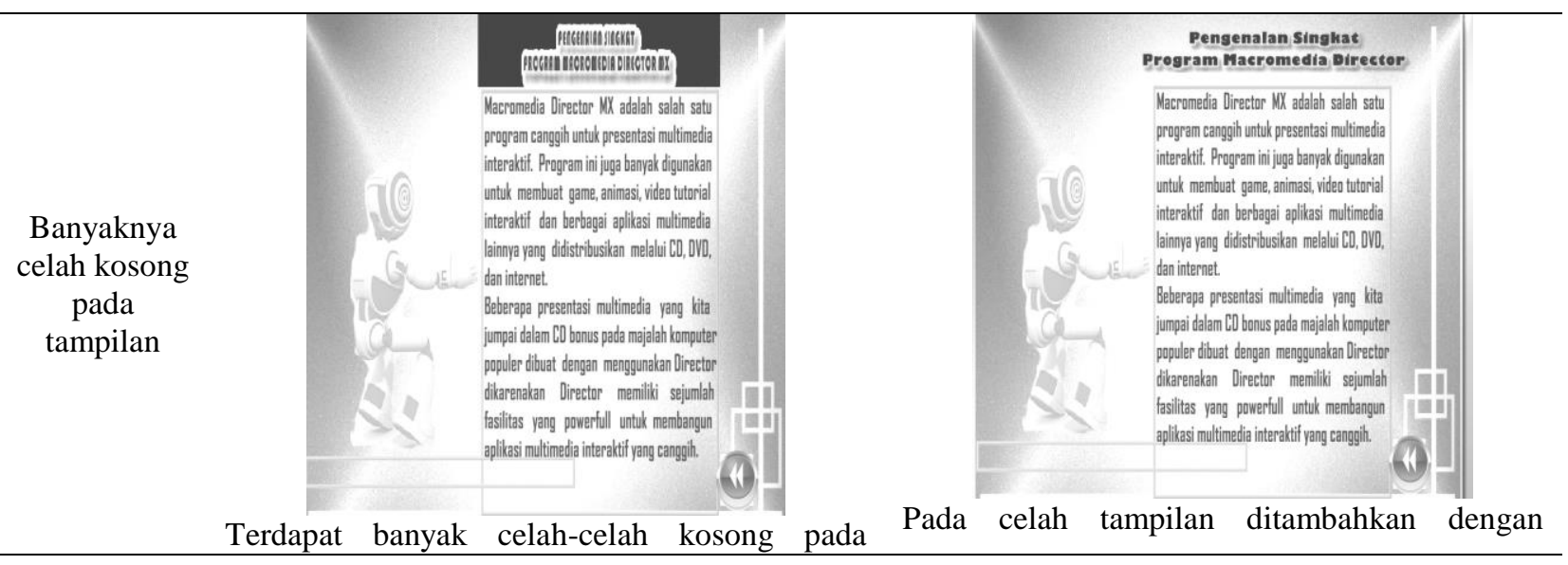




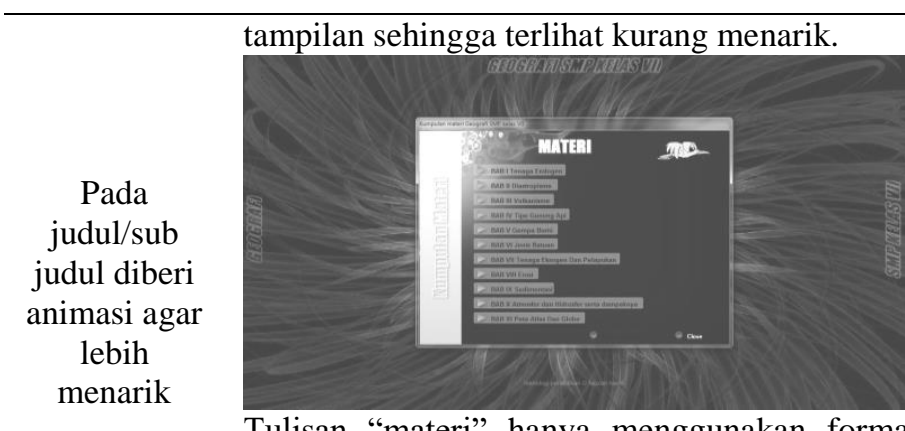

Tulisan "materi" hanya menggunakan format tulisan biasa.

Musik Musik dalam media terlalu banyak.

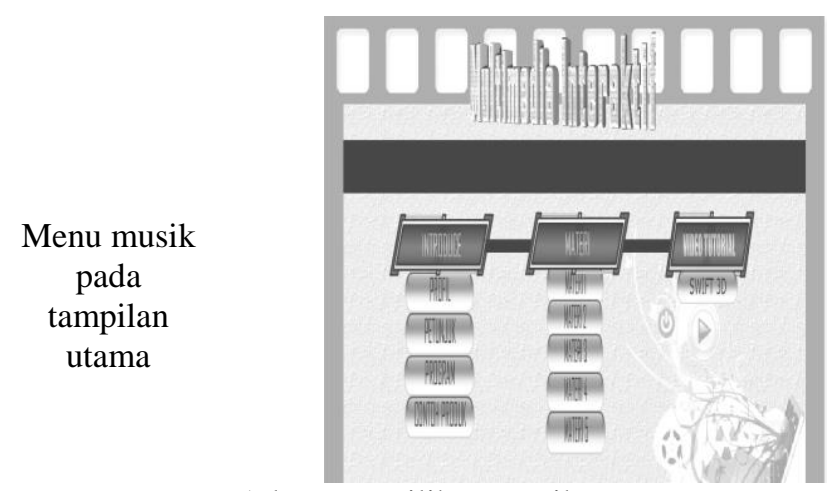

Ada menu pilihan musik.

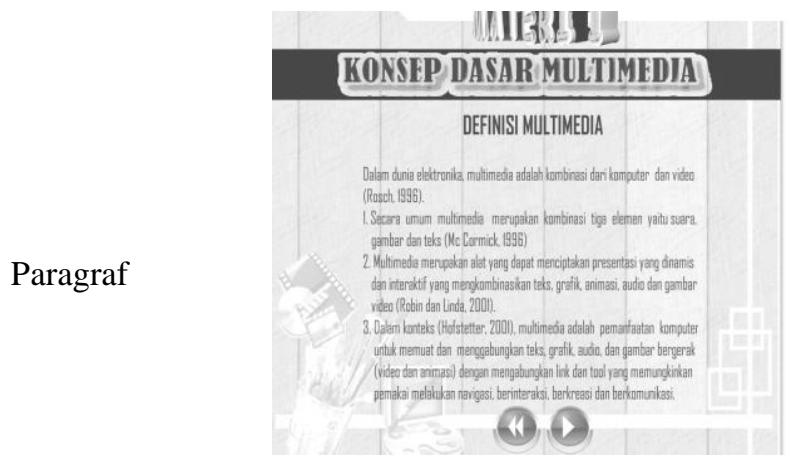

Pengaturan paragraf masih kacau/tidak teratur. gambar yang sesuai dengan materi.

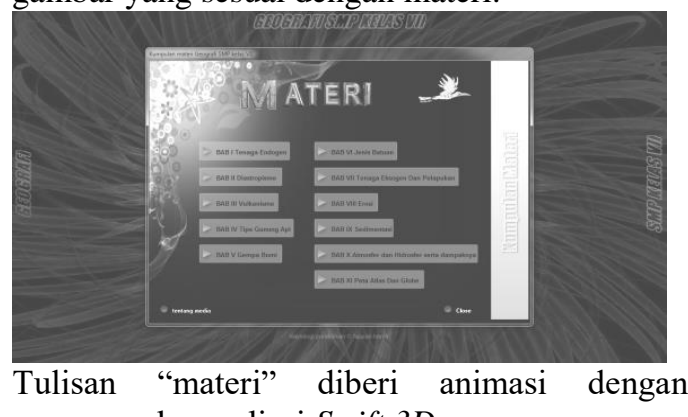
menggunakan apliasi Swift 3D.

Musik dijadikan 1 dalam media.

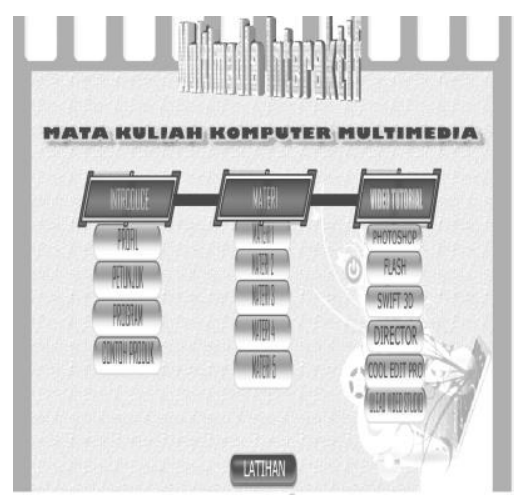

Menu pilihan dihilangkan.

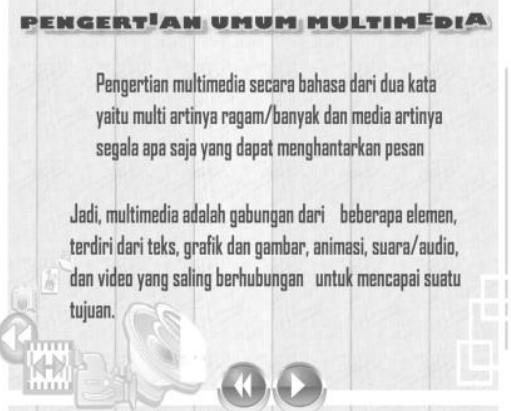

Pengaturan awal paragraf di beri 10 spasi agar lebih rapi pada tiap paragraf.

\section{Pembahasan}

Pengembangan multimedia interaktif ini diangkat dari permasalahan bahwa pada pembelajaran komputer multimedia pada program studi TP FIP UNP masih mengalami kesulitan dalam memahami dan mempraktikkan aplikasi serta mahasiswa cenderung pasif dalam proses pembelajaran. Maka untuk memudahkan mahasiswa dalam memahami materi tersebut dikembangkanlah multimedia interaktif dengan aplikasi Autorun Enterprise II didukung dengan aplikasi lainnya yang lebih menarik.

Menurut Daryanto (2010) multimedia interaktif adalah suatu multimedia yang dilengkapi dengan alat pengontrol yang dapat dioperasikan oleh pengguna, sehingga pengguna dapat memilih apa yang dikehendaki untuk proses selanjutnya. Hal ini sesuai dengan tujuan awal pengembangan produk yaitu untuk menciptakan pembelajaran yang dapat menarik minat mahasiswa untuk belajar.

Penelitian ini dilakukan untuk mengembangkan sebuah media pembelajaran berupa multimedia interaktif yang layak digunakan dalam proses pembelajaran.Agar dapat mengatasi permasalahan-permasalahan yang dihadapi dosen dan mahasiswa pada mata kuliah komputer multimedia. Untuk itu, dilakukan uji validitas dan uji pratikalitas yang berfungsi untuk mengetahui kelayakan media 
yang dikembangkan dengan melibatkan beberapa ahli dan subjek coba.

Menurut Sudjana (2004) uji validitas berkenaan dengan ketepatan alat ukur terhadap konsep yang diukur, sehingga betul-betul mengukur apa yang seharusnya diukur. Jadi, tujuan uji validitas adalah untuk mendapatkan kevalidan dan kesahihan informasi data yang diperoleh. Sedangkan uji praktikalitas merupakan suatu pengukuran/penilaian yang menunjukkan mudah atau tidak mudahnya suatu produk yang digunakan. Berikut ini hasil akhir validitas dan praktikalitas produk media pembelajaran interaktif setelah dikembangkan.

Tabel 5.

Hasil Akhir Validitas dan Praktikalitas

\begin{tabular}{|c|c|c|c|c|c|}
\hline \multicolumn{4}{|c|}{ Validitas } & \multirow{2}{*}{\multicolumn{2}{|c|}{$\begin{array}{l}\text { Praktikalitas } \\
\text { Kelayakan }\end{array}$}} \\
\hline & Materi & & Media & & \\
\hline Nilai & Kategori & Nilai & Kategori & Nilai & Kategori \\
\hline 85,71 & $\begin{array}{l}\text { Valid dengan revisi } \\
\text { ringan }\end{array}$ & 90,87 & $\begin{array}{l}\text { Valid dengan revisi } \\
\text { ringan }\end{array}$ & 88,10 & Sangat praktis \\
\hline
\end{tabular}

Dari Tabel 5. di atas, dapat ditarik kesimpulan bahwa produk multimedia interaktif ini memiliki kepraktisan sebagai produk yang membantu dosen dan siswa dan warga belajar pada umumnya sebagai alternatif media pembelajaran yang menarik dan simpel. Ini terlihat dari validitas materi dan praktikalitas kelayakan media tersebut. Selain itu, produk ini juga dapat membantu dan mempermudah proses belajar, memperjelas materi pelajaran dengan beragam visualisasi dan audiovisual dan dapat menarik minat siswa untuk belajar.

\section{SIMPULAN DAN SARAN}

\section{Simpulan}

Berdasarkan analisis data yang telah diuraikan di atas, maka dapat ditarik kesimpulan sebagai berikut :

1. Pengembangan media pembelajaran multimedia interaktif mata kuliah komputer multimediadi program studi teknologi pendidikan FIP UNP dengan menggunakan aplikasi Autorun Pro Enterprise II telah selesai dilakukan. Produk media interaktif ini dapat digunakan oleh mahasiswa sebagai salah satu sarana pendukung pembelajaran.

2. Hasil deskripsi data penilaian oleh validator dari aspek materi dan aspek media menunjukkan bahwa produk media multimedia interaktif dengan validitas materi sebesar 85,71dengan kategori "valid dengan revisi ringan", validitas media sebesar 84,17 dengankategori "valid dengan revisi ringan". Sehingga media yang dikembangkan dapat dikategorikan valid dengan revisi ringan.

3. Deskripsi data uji coba terbatas menunjukkan bahwa produk yang dilengkapi dengan aspek kepraktisan dengan variabel kriteria media interaktif tentang tampilan, kemudahan, penyajian materi dan kemanfaatan berdasarkan pandangan mahasiswa memperoleh persentase sebesar $\mathbf{8 8 , 1 0}$ dengan kriteria "sangat praktis"

\section{Saran}

Berdasarkan dari kesimpulan di atas, maka dianjurkan saran-saran sebagai berikut:

1. Berdasarkan penelitian yang telah dilakukan, media pembelajaran multimedia interaktif ini layak digunakan sebagai salah satu mediapembelajaran yang cukup menarik bagi dosen dan mahasiswa di jurusan KTP FIP UNP

2. Pengembangan media pembelajaran multimedia interaktif mata kuliah komputer multimedia ini sebaiknya dilakukan oleh tim pengembang yang tidak cukup hanya satu orang melainkan melibatkan pihak luar yang cukup kompeten.

3. Tahap pengembangan ini belum sempurna terkait pada batasan penelitian yang dilakukan belum sampai pada tahapan penyebaran atau disseminate yang mana merupakan tahap penggunaan produk pada skala yang lebih luas, sehingga penelitian ini disarankan agar dapat dikembangkan lagi dalam penelitian berikutnya. 


\section{DAFTAR PUSTAKA}

Adam, S., \& Syastra, M. T. (2015). Pemanfaatan Media Pembelajaran Berbasis Teknologi Informasi Bagi Siswa Kelas X SMA Ananda Batam. CBIS Journal, 3(2), 78-90. Retrieved from ejournal.upbatam.ac.id > index.php > cbis > article > download

Arda, Saehana, S., \& Darsikin. (2015). Pengembangan Media Pembelajaran Interaktif Berbasis Komputer untuk Siswa SMP Kelas VII. E-Jurnal Mitra Sains, 3(1), 69-77. Retrieved from jurnal.untad.ac.id > jurnal > index.php > MitraSains > article > download

Daryanto. (2010). Media Pembelajaran. Yogyakarta: Gava Media.

Emzir. (2012). Metodologi Penelitian Kualitataif Analisis Data. Jakarta: PT

\section{Raja Grafindo Persada.}

Nopriyanti, \& Sudira, P. (2015). Pengembangan Multimedia Pembelajaran Interaktif Kompetensi Dasar Pemasangan Sistem Penerangan dan Wiring Kelistrikan di SMK. Jurnal Pendidikan Vokasi, 5(1). Retrieved from journal.uinalauddin.ac.id , index.php , idaarah , article > download

Rahmat, S. T. (2015). Pemanfaatan Multimedia Interaktif Berbasis Komputer dalam Pembelajaran. Jurnal Pendidikan Dan Kebudayaan Missio, 7(2), 196-208. Retrieved from http://repository.stkipsantupaulus.ac.id/5/ 1/4Artikel_Jurnal_Stefanus_Rahmatseting_13_hal\%2C_196-208_.pdf

Sudjana. (2004). Dasar-dasar Proses Belajar Mengajar. Sinar Biru Algesindo. 